Volume 12, Issue 2, (2020) 72-85

www.ij-lt.eu

\title{
Model-based instruction to improve the concept of students on human anatomy: Primary School, Ethiopia
}

\begin{abstract}
Asrat Dagnew * Department of Teacher Education and Curriculum, Studies, College of Education and Behavioral Science, Bahir dar University, Post Box No: 79, Bahir Dar University Ethiopia. https://orcid.org/0000-00022804-1715
\end{abstract}

Aminat Endris, Department of Teacher Education and Curriculum Studies, College of Education and Behavioral Science, Bahir dar University, Post Box No: 79, Bahir Dar University Ethiopia.

\section{Suggested Citation:}

Dagnew, A. \& Endris, A. (2020). Model-based instruction to improve the concept of students on human anatomy: Primary School, Ethiopia. International Journal of Learning and Teaching. 12(2), 72-85. https://doi.org/10.18844/ijlt.v12i2.4618

Received date August 23, 2019; revised date December 26, 2019; accepted date March 22, 2020.

Selection and peer review under responsibility of Prof. Dr. Hafize Keser, Ankara University, Ankara, Turkey.

${ }^{\circ} 2020$ United World Centre of Research Innovation and Publication. All rights reserved.

\begin{abstract}
The purpose of this study was to improve the conceptual understanding of students using model-based teaching about the human skeletal system in grade seven. Quasi-experimental research was employed pre- and post-test, control and experimental group design. Out of four sections, two sections $(n=132)$ were selected using simple random sampling techniques. The data were gathered by tests, observation and informal assessment. The data obtained from tests were analysed quantitatively through mean, standard deviation, independent t-test and the observation and informal assessment data were analysed qualitatively. The pre-test results indicated that there was no significant mean difference and $p>0.05$ between the two groups. Similarly, the result of pre-informal assessment showed that students in both groups had common misconceptions about the topic. The post-test results revealed that model-based teaching approach exhibited significant changes compared to the traditional groups of students. From the results of this study, it is possible to conclude that the model-based teaching approach improves students' conceptual understanding, participations and clear misconceptions compared to the students taught by traditional teaching approach. Based on the finding it was recommended that the modelbased teaching approach should be encouraged for teaching and learning biology.
\end{abstract}

Keywords: Conceptual understanding, human anatomy, model-based instruction

* ADDRESS FOR CORRESPONDENCE: Asrat Dagnew, Department of Teacher Education and Curriculum Studies, College of Education and Behavioral Science, Bahir dar University, Post Box No: 79, Bahir Dar University Ethiopia

E-mail address: asratboza@yahoo.com 
Dagnew, A. \& Endris, A. (2020). Model-based instruction to improve the concept of students on human anatomy: Primary School, Ethiopia. International Journal of Learning and Teaching. 12(2), 72-85. https://doi.org/10.18844/ijlt.v12i2.4618

\section{Introduction}

The educational process includes methods and techniques that provided the students the basic information in a way that helps them embrace it as easily as possible, facilitate the direct access of the students to different sources and stimulate creativity and teamwork (Pop-pacurar \& Tirla, 2009). They define learning of science is essential in every educational system that aims to prepare citizens of one's nation for a productive life. In this regard, science education occupies a key position in the school curriculum of Ethiopia.

'Science is very essential for the development of technology, which served as a motor for our changing world. Therefore, students must understand science concepts because they can solve their problem as well as the problem of the world. Mostly, science teachers in the classroom teaching science using the lecture method are less likely achieved the desired objective. The main purpose of the science courses must be training students to acquire the required learning skills and beliefs toward learning and scientific knowledge to develop a capacity to think scientifically, to analyse critically, daily life and to integrate theory and practice. Moreover, science courses must be designed with the consideration that learning consists of iterative interactions that take place between students' existing conceptions and their new experiences (Temitope \& Deborah, 2015).'

Most of the time, model-based teaching is an instructional practice where students explore content using models and is used extensively in the areas of mathematics and science. Students are at the centre of the learning experience and take ownership of their own learning (Gabel \& Gabel, 2018).

The study that shows the importance of teaching using models has great value in teaching biology students to explore biological objects and phenomena that inflexible to perceive directly and they can easily to understand the science concepts (Mclachlan,2003). According to Chittleborough and Treagust, (2009), models are often seen as teaching tools that enhance the visualization of abstract concepts.

Similarly, Louca and \& Zacharia, (2011), modelling-based learning is an approach for teaching and learning in science whereby learning takes place through student construction of models as representations of physical phenomena that include representations of physical objects and their characteristics, physical entities and physical processes involved in the physical phenomena. This leads to an externalized representation of the underlying mechanism of a physical phenomenon and helps learners build an understanding of that mechanism.

Different researchers define modes in different ways. According to Mclachlan (2003), the study that shows the importance of teaching using models has great value in teaching biology, it directs students to explore biological objects and phenomena that inflexible to perceive directly and can easy to understand the science concepts. Models divided into two kinds such as structure models and process models. The structure models may be a representation of structures which are physical, mathematical or computergenerated forms. Such structure models enable us to visualize the inaccessible. A structure model should represent the phenomenon under investigation as closely as possible. A process model allows us to experiment on the inaccessible, to explore the consequences of changes or manipulations which in the real world may not be possible for practical or ethical reasons. Structure models help us see how something is made, while process models help us understand how something works. Structure models empower thinking by analogy, while process models empower thinking by analysis.

Similarly, Skjold (2012), a study model is an illustration or explanation of the phenomenon with features that are considered important. Models allow for multiple representations including physical or structural, functional and analogical. Mental models are implicit and not visible to others except through expression in external representations such as conceptual models. Conceptual models, on the other hand, are the explicit representations that allow the science phenomena in question to be more understandable and predictable for students. These explicit representations include graphs, computer simulations, diagrams, analogies, mathematical equations and physical models. The presence of teaching models in teaching-learning biology classroom strongly supports the process of delivering 
Dagnew, A. \& Endris, A. (2020). Model-based instruction to improve the concept of students on human anatomy: Primary School, Ethiopia. International Journal of Learning and Teaching. 12(2), 72-85. https://doi.org/10.18844/ijlt.v12i2.4618

information from teacher to students. The complex biological phenomenon can be easily explained to students such as human anatomy.

\subsection{Conceptual framework}

A conceptual framework is defined as a network or a 'plane' of linked concepts. Conceptual framework analysis offers a procedure of theorization for building conceptual frameworks based on the grounded theory method (Jabareen, 2009).

The present study has two main variables. They are explained by categorizing as independent variables and dependent variables.

\subsection{Independent variables}

Independent variables of the study were the received treatment. The treatment was the mode of instruction, namely model-based teaching approach and traditional teaching approach. The instructions applied on human skeletal system. On the other hand, times consist of three levels in the analysis of conceptual understanding measurements as time 1 , time 2 and time 3 . At time 1 , which corresponds to the beginning of the instruction for each topic, measure understanding level of groups as at pre-test implementation, students were at the onset of the treatment was administered to be able to compare the experimental and control groups prior scores in terms of collective variables and examine the change in their scores during the study. At time 2 which corresponds to during intervention students assessed classroom observation, conceptual understanding about the topic, their participation, interests, identify misconceptions and fill learning gap of students and all students were instructed human skeletal systems were administered to investigate the effect of treatment. At time 3 which corresponds to the end of the instruction for each topic, related conceptual understanding was, treatment was completed, evaluate the effect of treatments as post-test and related variables. The conceptual framework of the research is given as follows (Figure 1):

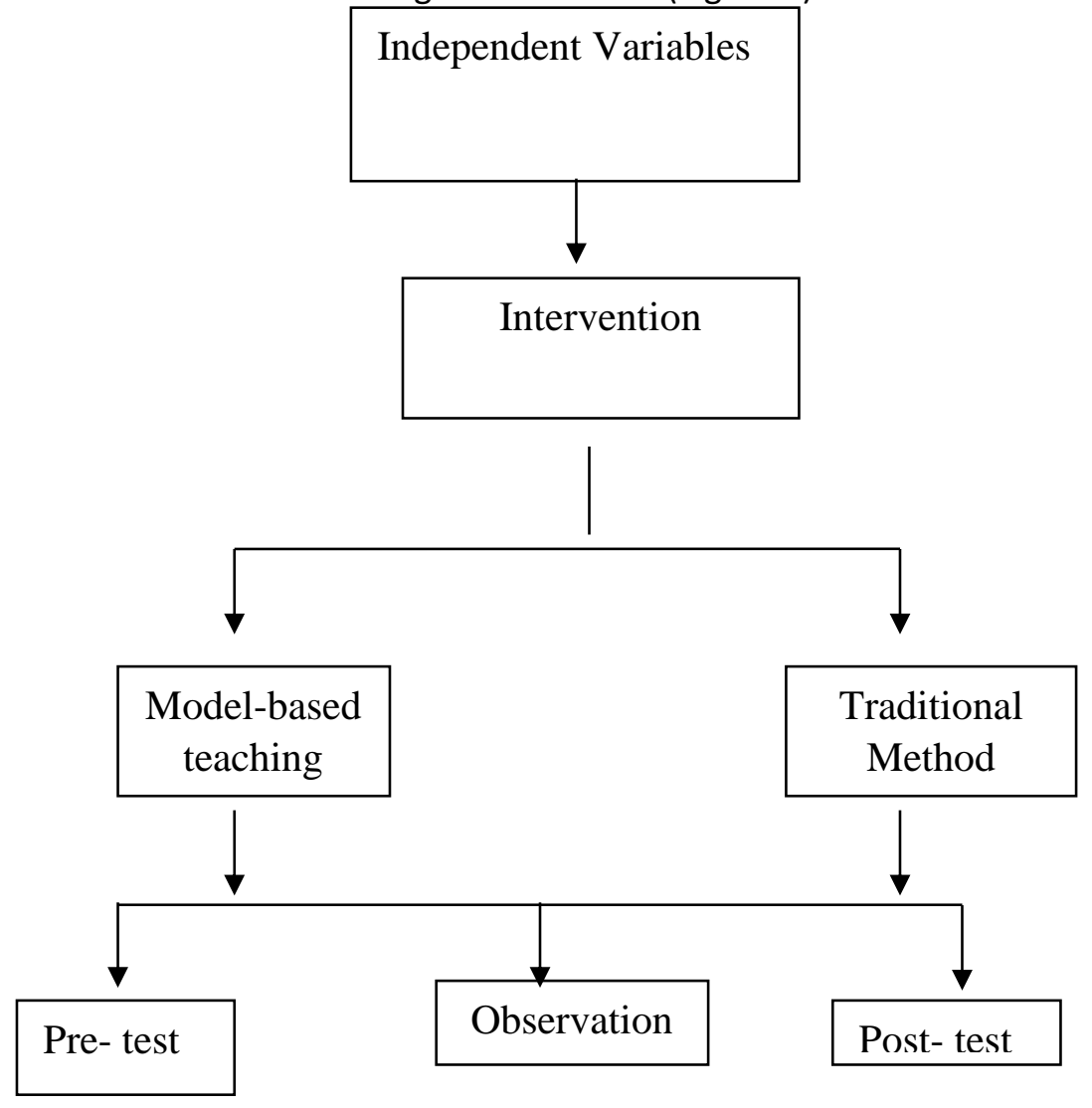

Figure 1. Conceptual framework of the research 
Dagnew, A. \& Endris, A. (2020). Model-based instruction to improve the concept of students on human anatomy: Primary School, Ethiopia. International Journal of Learning and Teaching. 12(2), 72-85. https://doi.org/10.18844/ijit.v12i2.4618

\subsection{Dependent variables}

Dependent variables of this study were improved the students' conceptual understanding on the unit of human skeletal system (i.e., structure and functions of skeletal system, bones, bone marrow, tissue, joints and tendons). Students' conceptual understanding in the unit of human skeletal system was measured by pre-test, post-test and classroom observation. Teaching using MBT approach is more effective than traditional once. Student conceptual understandings were improved, increased their participations, interests, clear their misconceptions and fill the gaps of learning difficulties.

\subsection{Research questions}

1. Is there a significant difference between model-based teaching approach and lecture method teaching approach when they thought human anatomy?

2. What is the effect of model-based biology instruction on students' conceptual understanding of human anatomy?

3. What is the interaction of students when they taught by model-based teaching approach?

\subsection{The aim of the study}

The main objective of this study is to improve students' conceptual understanding of human anatomy using model-based instructional approach in grade seven students. Specifically, the study was designed to identify the significant difference between the traditional teaching approach and modelbased teaching approach, to assess the effect of model-based biology instruction on students' conceptual understanding of human anatomy and to observe the interaction of students when they taught by model-based teaching approach.

\section{Students' misconceptions about human anatomy}

Many studies have attempted to gain a perspective on students' conceptual understanding of human body systems. The studies have shown that students do not fully understand the major concepts of human body systems and have knowledge deficiencies, misunderstanding and difficulty to interpret the subject. For example, according to Reiss \& Tunnicliffe (2001), most of the primary school students challenging to understanding the concepts of the human body because the concepts are complex and the internal organs are baffled. For instance, students know that they have bones, but they cannot indicate specifically to show by drawing. Other scholars James et al. (2007), students may struggle with these human anatomy topics based on the following common misconceptions: Humans may only use one or few organ systems for each activity they do (when, in fact, almost all human body systems are at work constantly); bones are not living tissues because of their solid, rock-like appearance (when, in fact, they contain cells, blood vessels and marrow) and muscles push on bones when, in fact, muscles do not move bones directly they contract, pulling on tendons, which attach muscles to bones, and the bones move.

Considering the skeletal system concept, the study conducted by Caravita \& Falchetti (2005), implied the perception of students regarding the bones; if the bones of a living organism are also living or non-living. The data were collected from 189 students ranged in age from 7 to 12 years who visited the Civic Zoological Museum. Each student was interviewed with the following questions: Are bones alive when they are inside the living body? What evidence do you have to this effect? What are bones made of? Can bones grow? How do they grow? And do children or newborn animals have the same bones as adults? The answers of students especially in secondary school level indicated a large frequency of the non-living statement toward bones. Moreover, students who stated bones as alive 
Dagnew, A. \& Endris, A. (2020). Model-based instruction to improve the concept of students on human anatomy: Primary School, Ethiopia. International Journal of Learning and Teaching. 12(2), 72-85. https://doi.org/10.18844/ijlt.v12i2.4618

mostly failed to express acceptable criteria to justify their answers. Rather, they argued the movement of bones or the presence of bone components like marrow as a criterion. These justification criteria were also observed a student who states the bones as not alive but in an opposite way. They explained for example, bones are not alive because they cannot move.

\section{Teaching methods}

The term teaching method refers to the general principles, pedagogy and management strategies used for classroom instruction. Teaching methods in the process of knowledge formation, the traditional teaching method and active learning pedagogies approaches are two major types of teaching approaches (Kolesnikova, 2016).

\section{Traditional teaching approaches}

In the context of this study, 'traditional teaching approaches' refer to the usual methods used by educators to teach science subjects. According to Kolesnikova (2016), the traditional teaching method, also known as the lecture method, is very common in education. Based on this lecture method, the educator can deliver the message through the 'chalk-and-talk' method. The traditional teaching method in schools is the teacher focus on the transfer of knowledge from the teacher to the student while students are a passive listener, traditional teaching methods are challenged for students inability to foster critical thinking, holistic learning environment among children (Ivić et al., 2016). Similarly (Richardson, n.d.), the traditional approach of teaching is the transmission model that promotes the traditional approach of teaching is the transmission model there is no interaction between prior and new knowledge. The information acquired from traditional teaching, if acquired at all, is usually not well integrated with other knowledge held by the students. Thus, new knowledge is often only brought forth for school-like activities such as exams and ignored at all other times. Traditional way of teaching encourages poor conceptual understanding and limited comprehension of learned in science concepts and ideas.

\section{Student-centre teaching approach}

Teachers must be responsible for the processes through which students obtain new knowledge. As Mathias, 2014, Miller, McNear, \& Metz, 2013 states that active learning is a student-centred teaching technique that uses various interactive, multimodal strategies to create a more engaging classroom setting compared with the traditional didactic lecture. Active learning is an instructional method that engages students in the learning process. Students are more engaged in the learning process and increasing understanding. The active learning format allows misconceptions to come up naturally in the learning process and students can recognize the mistakes they made and correct them which lead to better retention of the material and a deeper understanding. This approach moves the classroom from a teacher-centred to a more student-centred model; teachings must have to be responsive for the processes through which students obtain new knowledge.

In addition to Fernando \& Marikar (2017), active teaching advocates a participatory approach in which students actively participate in the learning process, emphasise that the active construction of knowledge by the learner. In modern teaching strategies focus on encouraging students in the teaching learning process such as problem-solving, constructing knowledge, interpreting ideas and sharing on the information. Similarly, Ivić et al., (2016), the teacher considers students as partners and therefore determines teaching strategies, ensures different approaches to information and provides help in acquiring new teaching contents. In such an environment, students take over the responsibility for learning, actively seek knowledge, construct it and give it meaning. 


\section{Research Design}

This study was conducted as design-based research. Design-based research 'is a systematic study of designing, developing and evaluating educational interventions.' In this study were used a quasiexperimental design of the study through the application of using experimental groups and control groups. All the two groups were taken a pre-test, post-test and observations were made. The experimental group has received the interventions of a model-based teaching approach, while the control groups with the traditional teaching approach as a control variable. The collected data using both qualitative and quantitative data collection instruments were used a pre-test, post-test and classroom observations.

\subsection{Source of data}

To investigate this research, the researcher collected the relevant source from Ewketfana primary school grade seven students by different data gathering techniques.

\subsection{Population of the study}

The populations of this study were grade seven students in Ewket fana primary school in the academic years of 2011 E.C. The total population is 260 students. The participant of this study was two sections of grade seven students out of four sections. The researcher chooses for grade seven students because, human anatomy concepts start at grade seven levels (Table 1).

Table 1. Population size

\begin{tabular}{ccccc}
\hline Name of school & \multicolumn{4}{c}{ Number of students } \\
\hline \multirow{3}{*}{ Ewket fana primary } & Sections & M & F & Total \\
school & A & 33 & 29 & 62 \\
& $\mathrm{~B}$ & 28 & 38 & 66 \\
& $\mathrm{C}$ & 29 & 37 & 66 \\
& $\mathrm{D}$ & 27 & 39 & 66 \\
& Total & 117 & 143 & 260 \\
\hline
\end{tabular}

\subsection{Sample size and sample techniques}

Ewket fana primary school students were taken as a target population of this study. Two sections from grade seven were selected using simple random sampling techniques out of four sections. Based on this data, the researcher selected two sections (C\&D) and grouped into two (the experimental group and the control group). The samples were used for the purpose of this study composed of 132 students (Table 2).

Table2. Samples size

\begin{tabular}{ccccc}
\hline Name of school & Groups & & Numbers of students \\
& & $\mathrm{M}$ & $\mathrm{F}$ & Total \\
Ewket fana primary school & & & & \\
& Experimental & 29 & 37 & 66 \\
& Control & 27 & 39 & 66 \\
& Total & 56 & 76 & 132 \\
\hline
\end{tabular}




\section{Intervention}

This intervention was conducted for 3 weeks. The intervention program consisted of three phases these are: First, the researcher was started given by the pre-test to learners to determine homogeneity in their knowledge of the topic, about 'Human Anatomy'. Second, the intervention was conducted after the administration of the pre-test for 3 weeks. The experimental group was taught using the modelbased teaching approach for the topic of human skeletal system concepts. At this time, lesson plan was applied using 5E instructional design model while the control groups were received traditional instructions using the only lecture methods and gathered information using observations and informal assessments' at the side of teaching. Finally, the researcher was given post-test to assess students' conceptual understanding (Table 3).

Table 3. Summary of the $5 E$ instructional model

\begin{tabular}{|c|c|}
\hline Phase & Summary \\
\hline Engagement & $\begin{array}{l}\text { The teacher or a curriculum task accesses the learners' prior knowledge and } \\
\text { helps them become engaged in a new concept through the use of short activities } \\
\text { that promote interest and provoke prior knowledge. The activity should make } \\
\text { connections between past and present learning experiences, expose prior } \\
\text { conceptions and organize students' thinking toward the learning outcomes of } \\
\text { current activities. }\end{array}$ \\
\hline Exploration & $\begin{array}{l}\text { Exploration experiences provide students with a common base of activities } \\
\text { within which current concepts (i.e., misconceptions), processes and skills are } \\
\text { identified and conceptual change is facilitated. Learners may complete lab } \\
\text { activities that help them use prior knowledge to generate new ideas, explore } \\
\text { questions and possibilities and design and conduct a preliminary investigation. }\end{array}$ \\
\hline
\end{tabular}

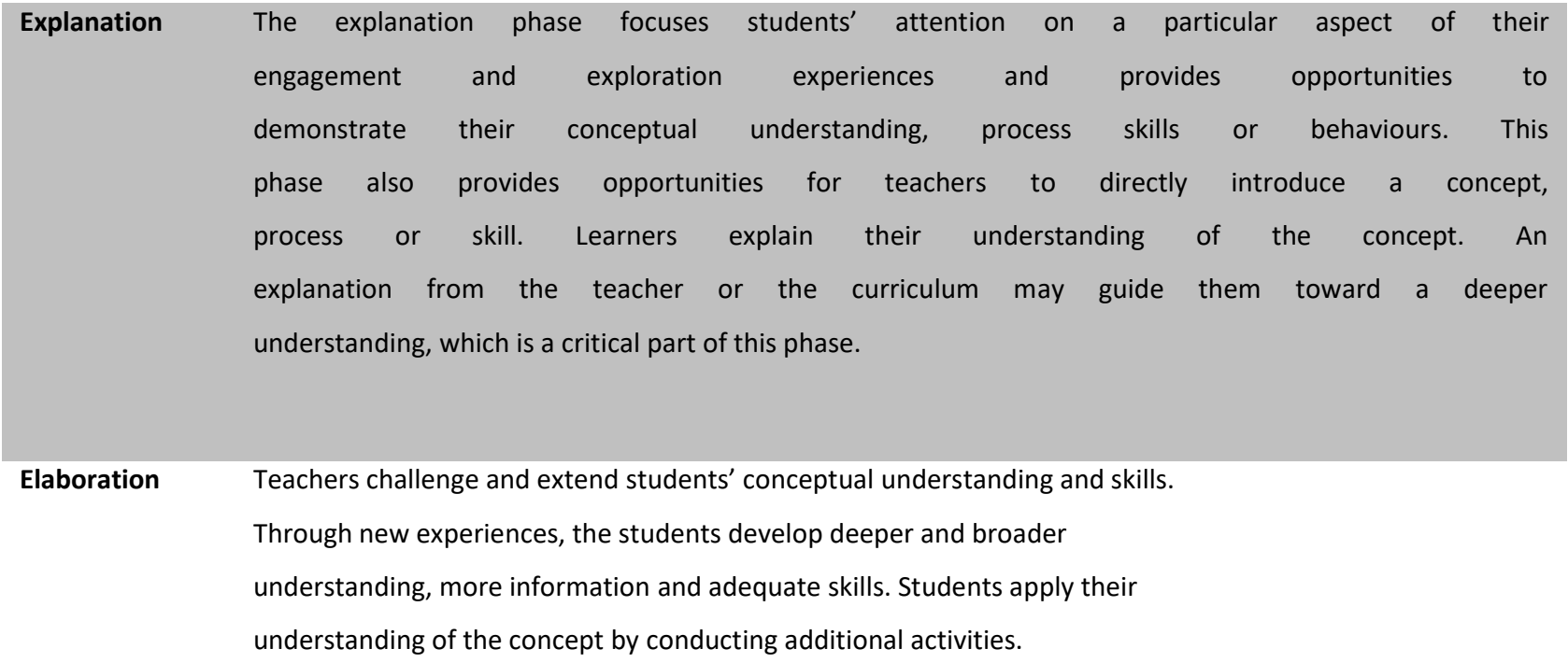




\section{Evaluation The evaluation phase encourages students to assess their understanding and abilities and provides opportunities for teachers to evaluate student progress toward achieving the educational objectives.}

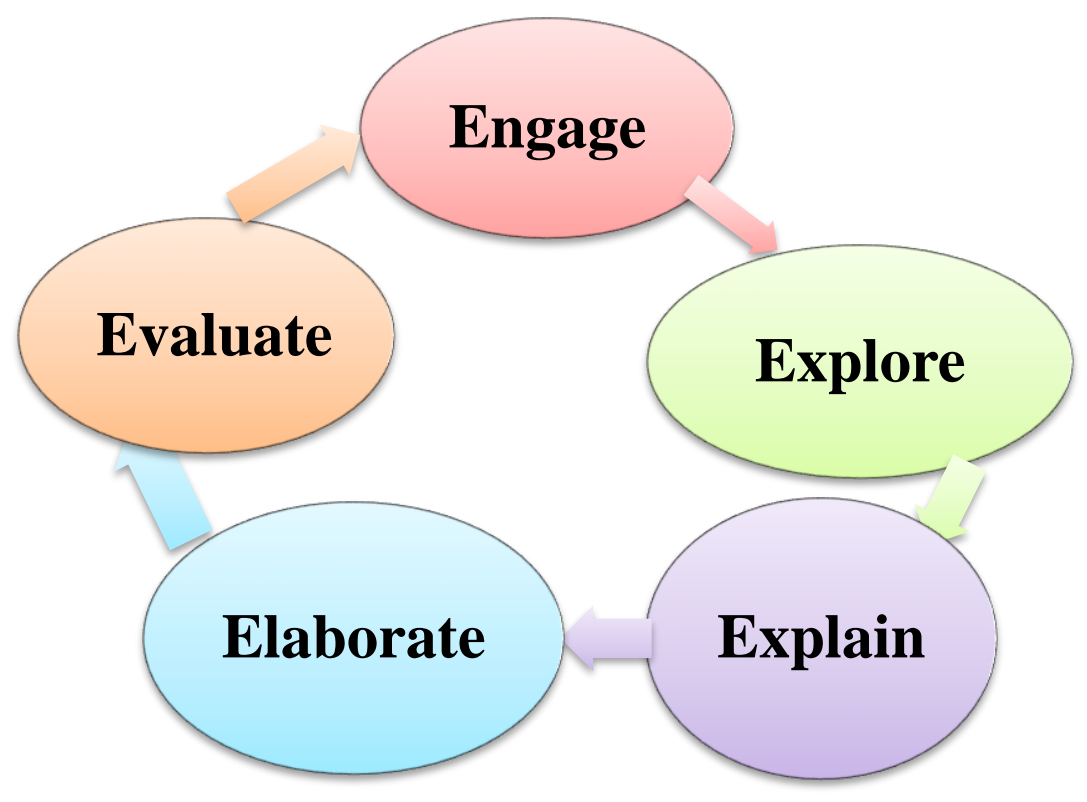

\subsection{Instrument of the study}

The data gathered tool to achieve the objectives of the study was pre-test, post-test and classroom observation. This tool was used to get adequate information from the sample of the study. All instruments were described as follows:

\section{Conceptual understanding measurement instrument}

These instruments were in the form of a test, which is pre-test, post-tests and classroom observation. Test includes 15 multiple choice items and its duration of time was $1 \mathrm{~h}$ and classroom observation was informally assessed students' progress.

\section{Pre-test}

The tools were an important tool to assess the students' prior knowledge and levels of understanding before the intervention started. This test helped to establish the homogeneity of the experimental and control group and also exhaustively covered the topic 'human anatomy'.

\section{Post-test}

The post-test was similar to the pre-test except for orders of the question. After the treatment, the researcher was given the post-test. This tool also important to know the progress of the students and measure conceptual understanding capacity through the lesson of human anatomy and the results were compared. The comparison was done between the experimental group and the control group's post-test scores. It was done to determine the groups which achieved higher than the other. 


\section{Classroom observation}

Observation involves the systematic viewing of people's actions and the recording, analysis, and interpretation of their behaviour. For this reason, the researcher was observed students during the intervention by checklists and informal assessments which used to evaluate a student's own performance, progress of knowledge and an investigating tool to find what prior knowledge of students, what their misconceptions, confusions what they had and filled the gap within timely feedback. Finally, the results of each observation were interpreted.

\subsection{Data collection procedure}

The data were gathered through pre-test, post-test and classroom observations keeping its procedure. Before beginning the actual data collection process the research outlined timetable about the whole work to make easy and effective the research process. First, the researcher was starting to administer the pre-test to learners to determine homogeneity in their knowledge of the topic, 'Human Anatomy'. The treatments were conducted after the administration of the pre-test for 3 weeks. The experimental groups were thought using the model-based teaching approach during this time the lesson plan was applied using 5E instructional design model while the control groups ware thought using traditional teaching approach the only lecture method and were taken informal assessments and observations at the side of teaching. Finally, the researcher was providing post-test to measure students' conceptual understanding.

\section{Data Analysis}

In this study, based on the nature of the research question, the data collected from the respondents were analysed using both qualitatively and quantitatively analysis techniques were employed. The data gathered through pre-test and post-tests were analysed using mean, standard deviation and independent sample t-test analysis. The SPSS (20 version) application software was employed to analyse quantitative data. In addition to these observations and informal assessments were also analysed qualitatively.

\section{Descriptive statically analysis of pre-test and post-test results and interpretation for both Groups}

Table 4. Pre-test results for descriptive analysis

\begin{tabular}{ccccc}
\hline Pre-test results & $\mathbf{n}$ & Mean & SD & Variance \\
\hline Control & 66 & 3.84 & 1.57 & 2.469 \\
Experimental & 66 & 3.81 & 1.60 & 2.582 \\
\hline
\end{tabular}

Table 4 shows the mean scores and variances comparison of the experimental and control group. This indicates that there is no statistical difference in the mean scores and variances of the experimental group $(\mathrm{M}=3.81, \mathrm{SD}=1.60$, $\mathrm{Var}=2.582)$ and control group $(\mathrm{M}=3.84, \mathrm{SD}=$ 1.57 , Var $=2.469$ ) and the mean difference in the pre-test between the experimental and control group is 0.03 . This means that the experimental and control groups have a very small difference in mean score and variances, indicated that the two groups started at the same level.

Table 5. Post-test results for descriptive analysis

$\begin{array}{llll}\text { Post-test scores } & \mathrm{n} & \text { Mean } & \text { SD }\end{array}$


Dagnew, A. \& Endris, A. (2020). Model-based instruction to improve the concept of students on human anatomy: Primary School, Ethiopia. International Journal of Learning and Teaching. 12(2), 72-85. https://doi.org/10.18844/ijlt.v12i2.4618

\begin{tabular}{ccccc}
\hline Control & 66 & 7.98 & 1.95 & 2.9 \\
\hline Experimental & 66 & 10.14 & 1.62 & 2.582 \\
\hline
\end{tabular}

Table 5 indicates the mean result experimental $(M=10.14, S D=1.62$ and Var $=3.52)$ group and control $(\mathrm{M}=7.79, \mathrm{SD}=1.95$ and $\mathrm{Var}=2.9)$ group for post-test. This indicates that there is a statistically significant difference in the mean scores and variances of the experimental group differ significantly their mean difference is 2.35 . This implies that there was a statistically significant difference in conceptual understanding between the students who instructed with model-based instruction and those instructed with traditional lecture method. This difference is statistically insignificant showing that the results could not happen by chance.

\section{Inferential statically analysis of pre-test and post-test for both groups}

Table 6. Independent sample t-test for pre-test

\begin{tabular}{c|c|c|c|c|c|c}
\hline Groups & \multicolumn{5}{|c}{ T-test for Equality of Means } \\
\hline $\begin{array}{c}\text { Experimental and } \\
\text { control }\end{array}$ & $\mathrm{T}$ & $\mathrm{Df}$ & Sig. (2-tailed) & $\begin{array}{c}\text { Mean } \\
\text { difference }\end{array}$ & $\begin{array}{c}\text { 95\% Confidence Interval of } \\
\text { the difference }\end{array}$ \\
\cline { 3 - 7 } & -110 & 130 & 0.913 & 0.03030 & -57759 & 0.51699 \\
\hline
\end{tabular}

When looks at Levene's test in Table 3, (Page, 21), sig significant (sig >0.05), the samples were equal variances assumed.

Table 6 shows the independent sample t-test there was not a significant difference between the mean scores of the experimental group and the control group for the pre-test, before administration of the intervention to the experimental group. There was no significant difference in the pre-test scores at alpha level $\alpha=0.05$, Sig (two-tailed) $>0.05, \mathrm{df}(130), t=0.110$ ) indicating that the difference in the mean score was not significant. This result illustrated that both the students in the control and experimental group were similar in abilities before the treatment was administered. Hence, the two groups are equivalent. This conclusion is supported by Field (2009), when the P-value is greater than the level of significance, set by the researcher, the null hypothesis is not rejected and the conclusion is that the two means did not differ significantly.

Table 7. Independent sample t-test for post-test

\begin{tabular}{|c|c|c|c|c|c|c|}
\hline Groups & \multicolumn{6}{|c|}{ T-test for equality of means } \\
\hline \multirow[t]{3}{*}{$\begin{array}{l}\text { Experimental and } \\
\text { control }\end{array}$} & \multirow[t]{2}{*}{$t$} & \multirow[t]{2}{*}{$\mathrm{Df}$} & \multirow[t]{2}{*}{ Sig. (2-tailed) } & \multirow[t]{2}{*}{$\begin{array}{c}\text { Mean } \\
\text { difference }\end{array}$} & \multicolumn{2}{|c|}{$\begin{array}{l}\text { 95\% Confidence Interval of the } \\
\text { difference }\end{array}$} \\
\hline & & & & & Lower & Upper \\
\hline & -7.516 & 125.505 & .000 & -2.34848 & -2.96683 & -1.73014 \\
\hline
\end{tabular}


Dagnew, A. \& Endris, A. (2020). Model-based instruction to improve the concept of students on human anatomy: Primary School, Ethiopia. International Journal of Learning and Teaching. 12(2), 72-85. https://doi.org/10.18844/ijlt.v12i2.4618

When looks at Levene's test in Table 3, sig significant (sig < 0.05), the samples were equal variances not assumed.

Table 7 shows the t-test comparison of the post-test score $(p=0.05)$ to the alpha level $(\alpha=0.0 .05)$. This conclusion is supported by Field, (2009), when the $p$-value is less than the level of significance, set by the researcher, the null hypothesis is rejected. This indicates that there are statistically significant differences in the mean scores of the experimental group differ significantly. Critical $t$-value ( $t$ crit $=$ 2.35 ) in the appendix, two-tailed and level of significance $(\alpha=0.0 .05)$, (Tcal (7.52) > Tcri (2.35), df 125.5, $\mathrm{p}(0.001)<0.05)$. This shows that the result not existed by chance; therefore, there is a significant difference between the experimental and control group result in model-based instruction varese lecture method.

Table 8. Effect of gender difference in pre-test and post-test

\begin{tabular}{|c|c|c|c|c|c|c|c|c|}
\hline \multirow{3}{*}{ Gender } & \multicolumn{8}{|c|}{ Group Statistic } \\
\hline & \multicolumn{4}{|c|}{ Pre-test } & \multicolumn{4}{|c|}{ Post-test } \\
\hline & $M$ & SD & $\mathrm{t}$ & $\begin{array}{l}\text { Sig.(2- } \\
\text { talied) }\end{array}$ & $M$ & SD & $\mathrm{t}$ & Sig.(p) \\
\hline Female & 3.9 & 1.60 & 0.33 & 0.72 & 9.1 & 2.2 & 0.66 & 0.509 \\
\hline Male & 3.7 & 1.57 & 0.33 & 0.72 & 8.9 & 2.1 & 0.66 & 0.509 \\
\hline
\end{tabular}

Based on an independent t-test results in Table 5, (see page 23), there was no significant difference in the score for male $(M=3.7, S D=1.57)$ and female $(M=3.9, S D=1.6) t(130)=0.33, p=0.72)$ for pretest while in the post-test results for male $(M=8.9, S D=2.1)$ and for female $(M=9.1, S D=2.2), t(130)=$ $0.66, p=0.509)$. Sins in both cases, the $p$-value obtained was greater than alpha level $(p>0.05)$, which was no significant differences in students conceptual understanding; these results suggest that gender difference does not have an effect on students conceptual understanding

\section{Discussion of the Results}

Based on the finding of this study, the researcher demonstrated the following discussion concerning the role of model-based teaching approach how practically they implemented to improve students' conceptual understanding in human anatomy topics. All finding of this study was stated based on the data of pre-test, post-test, informal assessment and observation.

Hence, the research questions of this thesis are:

1. Is there a significant difference between model-based teaching approach and lecture method teaching approach when they thought human anatomy?

2. What is the effect of model-based biology instruction on students' conceptual understanding of human anatomy?

3. What is the interaction of students when they taught by model-based teaching approach?

With regard to the first research question to compare model-based teaching approach and traditional teaching approach on students' conceptual understanding about human anatomy the data on the pre-test, post-test and observation revealed. In this study, before an independent sample t-test was carried out to check the normality and homogeneity of variance test of the data using Levene's test 
Dagnew, A. \& Endris, A. (2020). Model-based instruction to improve the concept of students on human anatomy: Primary School, Ethiopia. International Journal of Learning and Teaching. 12(2), 72-85. https://doi.org/10.18844/ijit.v12i2.4618

and histogram test. The results could lead to the researcher to the conclusion that both groups were homogenous and have equal variance terms conceptual understanding before giving the treatment to the experimental group, after checking the normality and the variance, independent sample t-test was carried out. There were no significant differences mean scores between the experimental groups $(\mathrm{M}=$ $3.81, \mathrm{SD}=1.60, \mathrm{Var} .=2.58)$ and control group $(\mathrm{M}=3.84, \mathrm{SD}=1.57, \mathrm{Var} .=2.469$ ) on pre-test scores (see Table 3), both groups were similar level before the intervention was administered.

In addition, independent samples t-test was performed to check the differences in the pre-test score at alpha level $(\alpha=0.05, p>0.05, d f=130, t=0.110)$. Supported by Field, (2009), when the $p$-value is greater than the level of significance, set by the researcher, the null hypothesis is not rejected. This indicates that there were no statistically significant differences in the mean scores of both groups of the pre-test scores.

When see the post-test scores of the experimental and control group are statistically significant difference these confirm the existence of evidence to prove change in the mean score experimental groups $(M=10.14, S D=1.62$, Var. $=2.582)$ while the control groups of mean score $(M=7.9, S D=1.95$, Var. = 2.9) (Table 4) and mean difference were 2.24 due to implementation of model-based teaching of experimental groups. To check differences by another way, the independent samples t-test was supported by Field, (2009), when the p-value is less than the level of significance, set by the researcher, the null hypothesis is rejected. The t-test results indicated that the experimental group scores were, statistically significantly critical $t$-value ( $t$ crit $=2.35$ ) in the appendix) and two-tailed (at $\alpha=0.05, p<$ 0.05 DF (130), $t=7.52$ ).

The results of the analysis revealed that the experimental groups of students' performance were better than that of the control group and a significant difference between the mean scores of the two groups were observed. This was due to the use of the model-based instructional approach in the experimental group. According to Jackson et al., (2008), modelling instruction program emphasises active learning student construction of conceptual knowledge. Similarly, studies conducted by (Min et al., 2014), using a teaching model in the biology classroom his finding showed that students develop a better understanding of abstract concepts.

The significant difference between model-based teaching approach and traditional teaching approach when they thought human anatomy is shown above and it also determined the effect of a model-based teaching. The model-based instructional approach improves their understanding significantly for students in experimental groups, higher than those in the traditional instructional groups of teaching approach about human anatomy.

Through observational assessment learning using model-based teaching approach the well-known misconceptions of many students was changed. The students' participation has increased on those experimental groups during the model-based teaching; students clear their misconceptions were pay attention to the lesson gradually increase their participation, interests. According to Mclachlan, (2003), the study that shows the importance of teaching using models has great value in teaching biology, it directs students to explore biological objects and phenomena that inflexible to perceive directly and easy to understand the science concepts. The results of this study revealed that during preparation for model-based teaching human anatomy in particular misconceptions well known from literature should be included. On this result indicated that students perform better by discussing those wrong answers and with the help of the teacher they grab successfully the scientific model. One of the researchers' roles as a teacher in the classroom to help students, bridge the gap between their prior knowledge and new concepts to improve conceptual understanding. One way to do this is informatively assessed students along the way. It is imperative to understand where students' knowledge begins when starting a new unit of study so that teachers can be better, understanding their misconceptions. It is also equally important to continually monitor students' progress and re-teach concepts to build their conceptual knowledge. 
Dagnew, A. \& Endris, A. (2020). Model-based instruction to improve the concept of students on human anatomy: Primary School, Ethiopia. International Journal of Learning and Teaching. 12(2), 72-85. https://doi.org/10.18844/ijit.v12i2.4618

\section{Summary and Conclusion}

\section{Summary}

The main purpose of the study was to improve students' conceptual understanding of human anatomy topics for grade seven Ewket fana primary school students using model-based teaching approach. The data collected by tests, classroom observation and informal assessments'. Based on the analyses made on the data, summary of the findings are forwarded as follows:

$>$ The mean for the experimental and control group pre-test scores was statistically not significant. This implied that the control and experimental group started at the same level. No group was superior to the other.

$>$ The mean for the experimental and control group post-test scores was statistically significant. The fact that the control and experimental group started at the same level, then the difference that was observed between the post-test scores of the two groups was due to the treatment. The experimental group outperformed the control group. The use of model-based teaching was, therefore, more successful than the traditional lecture method.

$>$ The informal assessments observational findings showed that students clear their misconception and increase their interests towards the topic.

$>$ The research using visuals models as a teaching method stimulates thinking and improves the

\section{Conclusion} learning environment in a biology classroom.

In this study, an intervention was applied in two groups carried out for 3 consecutive weeks. After the intervention, analysis of the results revealed that the experimental group outperformed the control groups in a special conceptual understanding of measurement tests. Due to the significant and meaningful results in the experimental group, superiority of model-based teaching is confirmed. On the other hand, model-based learning instruction has an effect on improving students' conceptual understanding, participation and interests. The students engaged in experimental groups gradually increase their participation; clear their misconceptions and paying attention to the lesson during the model-based teaching. In general, as revealed under the results of independent t-test, learning using model-based teaching approach is better than the lecture method approach. According to Min et al., 2014), models are visual representations that a powerful tool because they help to make complex biological phenomenal to simple. Model-based teaching is intuitively a powerful tool for conceptual change and inherent to the process of science.

Finally, the result determined that students' understanding of biology class human anatomy topics can be improved and they became more interested in biology. Thus, from the results of this study, it is possible to conclude that the model-based teaching approach is a more effective method to contribute students' conceptual understanding when they learn to human anatomy in biology.

\section{Recommendations}

The study's results can also lead to a number of possible recommendations to different concerned bodies regarded by their responsibilities.

$>$ The model-based instructional has a positive effect on students' conceptual understanding hence teachers should be encouraged to employ it more in the teaching biology.

$>$ Teachers may be given importance to the students' opinion regarding the models understanding.

$>$ Teachers should try as much as possible to use these models in the teaching of difficult concepts in biology.

$>$ School principals encourage biology teachers to use models by preparing enough instructional materials like model of skeletal system.

$>$ In addition to their school principals also add additional classroom to minimize large class size.

$>$ Studies should consider these views in designing the curricula, textbooks, teaching activities and materials and teacher educational processes. 
Dagnew, A. \& Endris, A. (2020). Model-based instruction to improve the concept of students on human anatomy: Primary School, Ethiopia. International Journal of Learning and Teaching. 12(2), 72-85. https://doi.org/10.18844/ijlt.v12i2.4618

\section{References}

Caravita, S., \& Falchetti, E. (2005). Are bones a live? Journal of Bilogical Education, 39(4), 163-170.

Chittleborough, G.D., \& Treagust, D.F. (2009). Why Models are Advantageous to Learning. Educación Química, 20(1), 12-17.

Fernando, S. \& Marikar, F. (2017). Constructivist teaching/learning theory and participatory teaching methods. Journal of Curriculum and Teaching, 6(1), 110-122. https://doi.org/10.5430/jct.v6n1p110

Field, A. (2009). Discovering Statistics Using SPSS (3 $3^{\text {rd }}$ edition). Thousand Oaks: SAGE Publications.

Gabel, D., \& Gabel, D. (2018). Enhancing the conceptual understanding of science. Enhancing the Conceptual Understanding of Science, 81(2), 70-76.

Ivić, S., Gortan, V., \& Gortana, P.V. (2016). Frequency of applying different teaching strategies and social teaching methods in primary schools. Journal of Education and Practice, 7(33), 66-71.

Jabareen, Y. (2009). Building a conceptual framework: Philosophy, definitions, and procedure. International Journal of Qualitative Methods, 8, 49-62.

Jackson, J., Dukerich, L., \& Hestenes, D. (2008). Modeling instruction: An effective model for science education the authors describe a modeling instruction program that places an emphasis on the construction and application of conceptual models of physical phenomena as a central aspect of learning and d. Science Educator, 17, 10-15. Retrieved from http://www.modeling.asu.edu.

James, T., Calvo, R., \& Kenneth, C. (2007). Human biology teacher's edition. (1 $1^{\text {st }}$ ed). Boston MA: McDougal Littell Science.

Kolesnikova, I. (2016). Combined teaching method: An experimental study. World Journal of Education, 6(6), 51-59. https://doi.org/10.5430/wje.v6n6p51

Louca, L., \& Zacharia, Z. (2011). Modeling-based learning in science education: Cognitive, metacognitive, social, material and epistemological contributions. Educational Review, 64, 471-92. https://doi.org/10.1080/00131911.2011.628748.

Mathias, A. (2014). Active learning in the science classroom. Honors Projects Paper, No. 113, (pp. 1-32).

Mclachlan, J. (2003). Using models to enhance the intellectual content of learning in developmental biology. The International Journal of Developmental Biology, 229, 225-229.

Miller, C., McNear, J., \& Metz, M. (2013). A comparison of traditional and engaging lecture methods in a large, professionallevel course. AJP: Advances in Physiology Education, 37(4), 347-355. https://doi.org/10.1152/advan.00050.2013

Min, K.J., Jackman, J.K., \& Chan, J.C.K. (2014). Visual models for abstract concepts toward better learning outcomes and selfefficacy. Psychology Conference Papers, Posters, and Presentations.

Pop-Pacurar, I., \& Tirla, F. (2009). Models role within active learning in biology. A case study. Acta Didactica Napocensia, 2(2), 41.

Reiss, M.J., \& Tunnicliffe, S.D. (2001). Students' understandings of human organs and organ systems. Research in Science Education, 31, 383-399. https://doi.org/10.1023/A.

Skjold, B. (2012). Teaching about scientific models in a science content course. Educación Química, 23(4), 451-457.

Temitope, S.B., \& Deborah, T.A. (2015). Ordeals of physics instruction in Nigerian secondary schools: Way forward for the attainment of global competitiveness. Journal of Education and Practice, 6(20), 87-97. 